\title{
EPSL
}

ELSEVIER

Earth and Planetary Science Letters 121 (1994) 533-547

\section{The age of the Tortonian/Messinian boundary}

\author{
W. Krijgsman ${ }^{\text {a }}$, F.J. Hilgen ${ }^{\text {b }}$, C.G. Langereis ${ }^{a}$, W.J. Zachariasse ${ }^{b}$ \\ ${ }^{a}$ Paleomagnetic Laboratory, Fort Hoofddijk, Budapestlaan 17, 3584 CD Utrecht, The Netherlands \\ ${ }^{b}$ Department of Geology, Institute of Earth Sciences, Budapestlaan 4, 3584 CD Utrecht, The Netherlands
}

(Received April 28, 1993; revision accepted December 10, 1993)

\begin{abstract}
The Tortonian/Messinian boundary is marked by the first occurrence datum (FOD) of Globorotalia conomiozea which is found all over Crete in open-marine marls with good palaeomagnetic properties. Within the framework of the MIOMAR project, the previously studied sections of Langereis et al. [1] have been extended and (partly) resampled. Here, we present new magnetostratigraphic and biostratigraphic results from sections on eastern Crete (Faneromeni), central Crete (Kastelli) and western Crete (Potamida and Skouloudhiana) supplemented by cyclostratigraphic data.

The recently developed geomagnetic polarity time scale (CK92) of Cande and Kent [2] allows an unambiguous correlation of the polarity sequences on Crete. The FOD of $G$. conomiozea occurs in the reversed interval of anomaly C3Bn.1r. This leads to a new age determination of 6.92 Ma for the Tortonian/Messinian boundary and a duration of $1.76 \mathrm{Myr}$ for the Messinian. A slightly modified version of CK92-if we use more recent age estimates-provides an age of $7.10 \mathrm{Ma}$ and a duration of $1.78 \mathrm{Myr}$, respectively.

Bipartite sedimentary cycles are distinctly present in the Cretan sections studied. Assuming that these cycles are precession-induced and using an average periodicity of $21.7 \mathrm{kyr}$ enables us to independently estimate the duration of the successive individual polarity zones. The astronomically derived durations of the Cretan polarity zones are in good agreement with CK92, but are approximately $10 \%$ shorter.
\end{abstract}

\section{Introduction}

The Tortonian/Messinian (T/M) boundary is defined in section Falconara on southern Sicily at the level which corresponds with the first occurrence of the Globorotalia conomiozea group [3,4]. Most attempts to date the $\mathrm{T} / \mathrm{M}$ boundary were based on correlating magnetostratigraphic records of Mediterranean $\mathrm{T} / \mathrm{M}$ boundary sections with the Geomagnetic Polarity Time Scale (GPTS).

$\overline{\text { [PT] }}$
Direct magnetostratigraphic control of the boundary stratotype at Falconara itself is not possible because the entire section is subrecently remagnetised [5]. Upper Miocene sections on Crete, however, proved to be of excellent palaeomagnetic quality and resulted in a first reliable magnetostratigraphy for the $\mathrm{T} / \mathrm{M}$ boundary in the Mediterranean [1]. On Crete, $G$. conomiozea invariably first occurs in a short interval of reversed polarity, which was correlated with the reversed subchron of Chron 5 (anomaly 3An.1r) in the then available GPTS [6]. This correlation resulted in an age of 5.6 Ma for the FOD of $G$. 
conomiozea and, consequently, also for the $\mathrm{T} / \mathrm{M}$ boundary. Mainly on the basis of biostratigraphic arguments, this calibration was questioned by Berggren et al. [7]. They correlated the same Cretan polarity sequence differently to the geomagnetic polarity time scale-correlating the reversed $\mathrm{T} / \mathrm{M}$ boundary interval with the upper reversed interval of Chron 6-and obtained an age of 6.1 Ma. Channell et al. [8], however, found the FOD of $G$. conomiozea in a normal polarity interval at ODP Site 654 in the Tyrrhenian Sea. They derived an age of $6.44 \mathrm{Ma}$ or $5.40 \mathrm{Ma}$, pending two different interpretations of the nannofossil record [9]. Magnetostratigraphic studies from outside the Mediterranean yielded similar ambiguous results with ages ranging between 5.6 and $6.44 \mathrm{Ma}$ for the FOD of $G$. conomiozea [10-14]. For the actual dating of the $\mathrm{T} / \mathrm{M}$ boundary these studies are considered less critical because it is questionable whether the FOD of $G$. conomiozea, which represents a migratory event in the Mediterranean [15,16], is globally synchronous [17].

An accurate age for the FOD of $G$. conomiozea and hence the $\mathrm{T} / \mathrm{M}$ boundary will also provide the exact duration of the Messinian, the termination of which is now accurately dated [see 18 , and references therein]. The age of the $T / M$ boundary is thus an essential parameter for understanding the processes that took place during the Messinian, a period marked by evaporite formation in the Mediterranean (Messinian "salinity crisis"). To provide an unambiguous magnetostratigraphic correlation of the boundary to the GPTS, we decided to restudy the Cretan sections of Langereis [19]. These sections contain distinct sedimentary cycles of various types $\left(\mathrm{CaCO}_{3} \mathrm{cy}-\right.$ cles, sapropels). These sedimentary cycles are similar to the cycles which have been found in the Mediterranean Plio-Pleistocene and which were correlated to the astronomical cycle of precession $[20,21]$. We initially aimed to estimate the duration of the successive individual polarity zones on Crete, based on the number of presumably precession-related sedimentary cycles per polarity zone. These estimates can then be compared with the duration of successive (sub)chrons in the GPTS. A re-evaluation of the Cretan sections has become especially relevant, since Cande and Kent [2] have constructed a new geomagnetic polarity time scale (CK92) in which they recognise two additional normal subchrons in the reversed interval of Chron 6 (C3Br.1n, C3Br.2n). This resulted in an essentially different polarity pattern for the Late Miocene.

The present study is part of the MIOMAR (MIOcene Marine Archives Reading) project. Major aims are to extend the astronomical polarity time scale into the Miocene and to develop an integrated magnetostratigraphy, multiple biostratigraphy, cyclostratigraphy and isotope stratigraphy for the late-Middle to Late Miocene in the Mediterranean. In this paper, we focus on the detailed magnetostratigraphy of the Cretan sec-

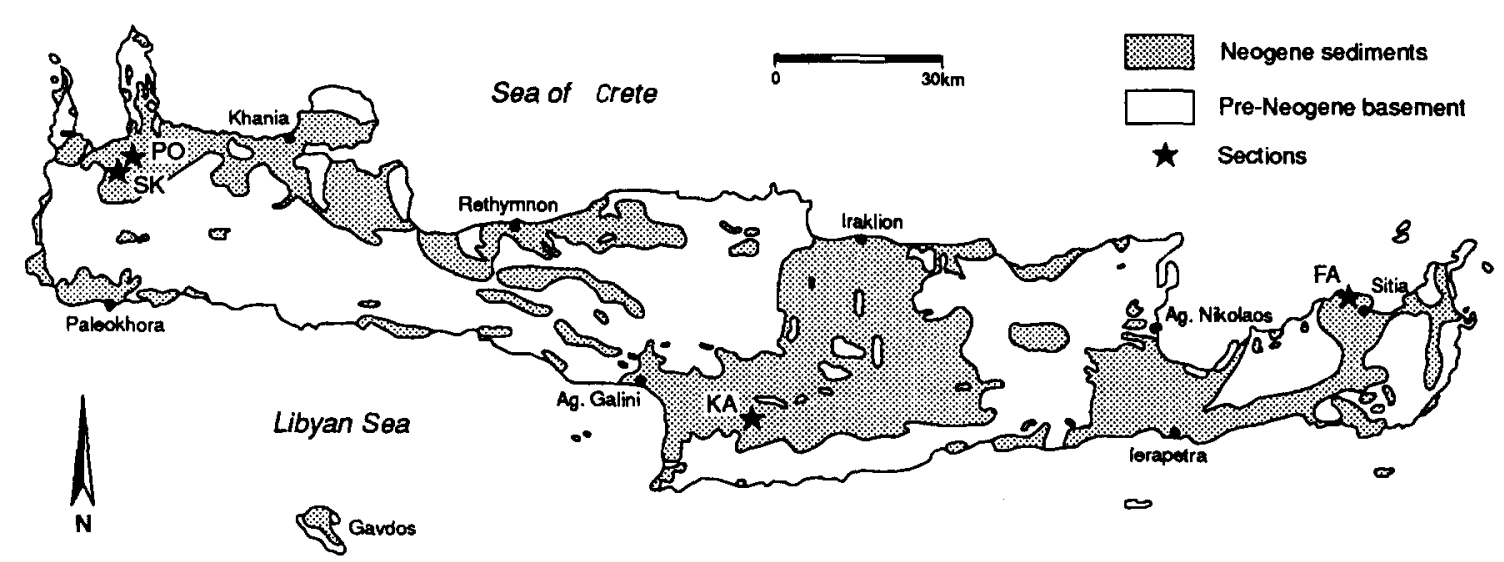

Fig. 1. Location of the Cretan sections ( $F A=$ Faneromeni; $K A=$ Kastelli; $S K=$ Skouloudhiana; $P O=$ Potamida). 
tions, their cyclostratigraphy and the correlation to the CK92 geomagnetic polarity time scale. The precise correlation of the sedimentary cycles to the astronomical record will be subject of future studies.

\section{Sections and sampling}

All over Crete, a transition from sandy littoral deposits to open-marine marls is observed in the Tortonian. Generally, the marls are again over-

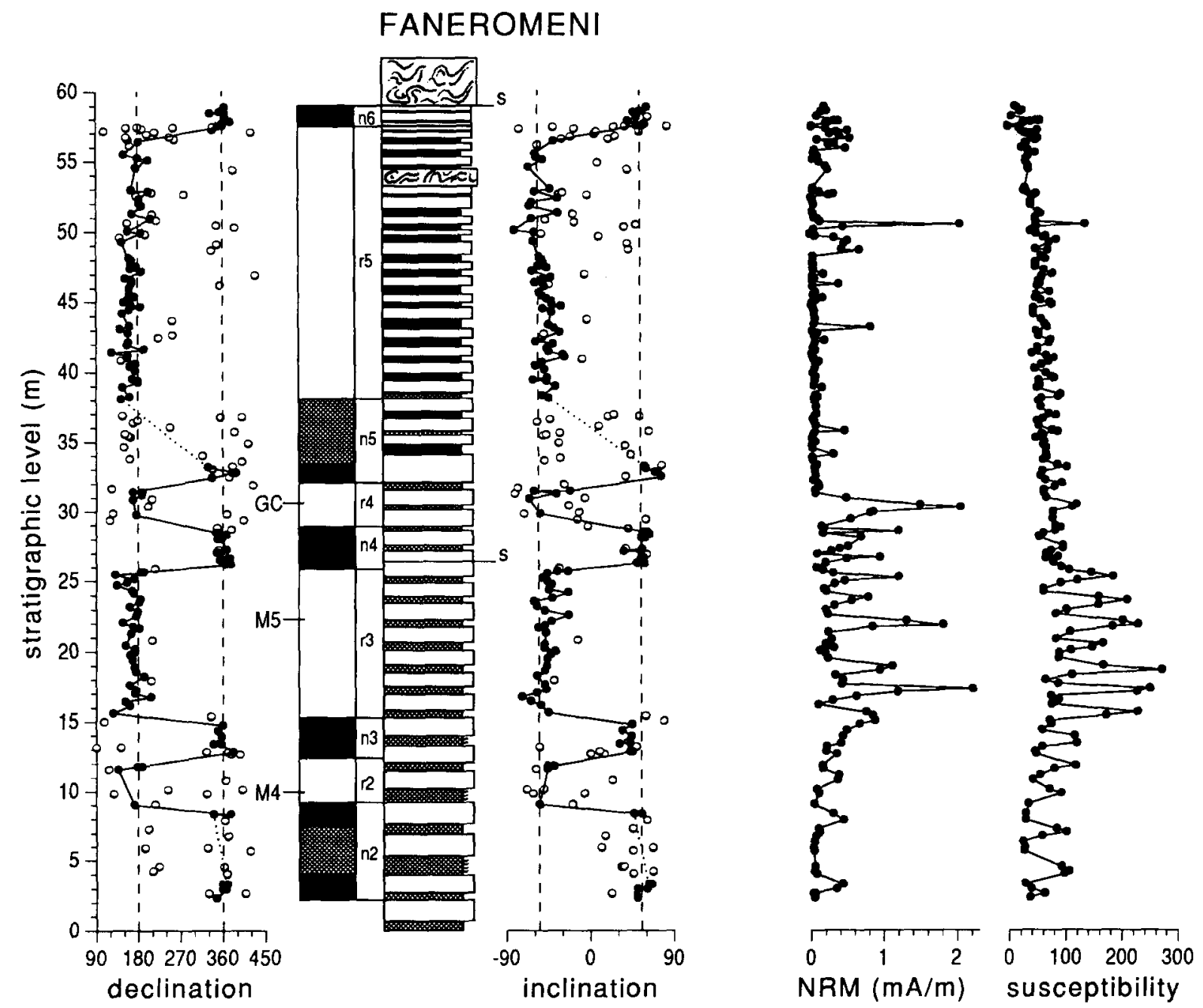

Fig. 2. Magnetostratigraphy, lithology, susceptibility and NRM-intensities of the Faneromeni section. Dots represent reliable directions, circles represent low-intensity samples which are difficult to interpret. Dashed lines indicate declination and inclination of the geocentric axial dipole field for the present latitude of Crete. In the polarity column, black denotes normal polarity zones and white denotes reversed polarity zones; shaded interval denotes zone with undefined polarity. The lithostratigraphic column displays cyclic sedimentary variations of white (white), grey (grey) and sapropeletic (black) layers. Biostratigraphic datum levels are: $G C=$ FOD of Globorotalia conomiozea, $M 5=$ FOD of Globorotalia menardii form 5, M4 = LOD of Globorotalia menardii form 4. $s=$ bedding-parallel shear plane. 
lain by shallow-marine beige to whitish marls and limestones of Messinian age. We extended and resampled in more detail the Faneromeni and Kastelli sections [19] and part of the Skouloudhiana section [1]. Where possible and appropriate, we studied also the cyclostratigraphy of thecyclically bedded-sections in detail, a study we had previously omitted.

The Faneromeni section is located along the north coast of Crete, just west of Sitia (Fig. 1) and consists mainly of blue-grey marls. The section has a thickness of $60 \mathrm{~m}$ and is excellently ex- posed. It contains an undisturbed and complete succession except for a bedding-parallel shear plane in the middle part (Fig. 2). In the upper part of the section a $1.5 \mathrm{~m}$ thick slump level is present, which comprises a single sedimentary cycle. A transition from open-marine marls to shallow-marine carbonates marks the uppermost part of the section. Sampling was continued up to a bedding-parallel shear plane which forms the base of a major slump level.

The Kastelli section on central Crete (Fig. 1) has a thickness of $60 \mathrm{~m}$ and consists of sediments

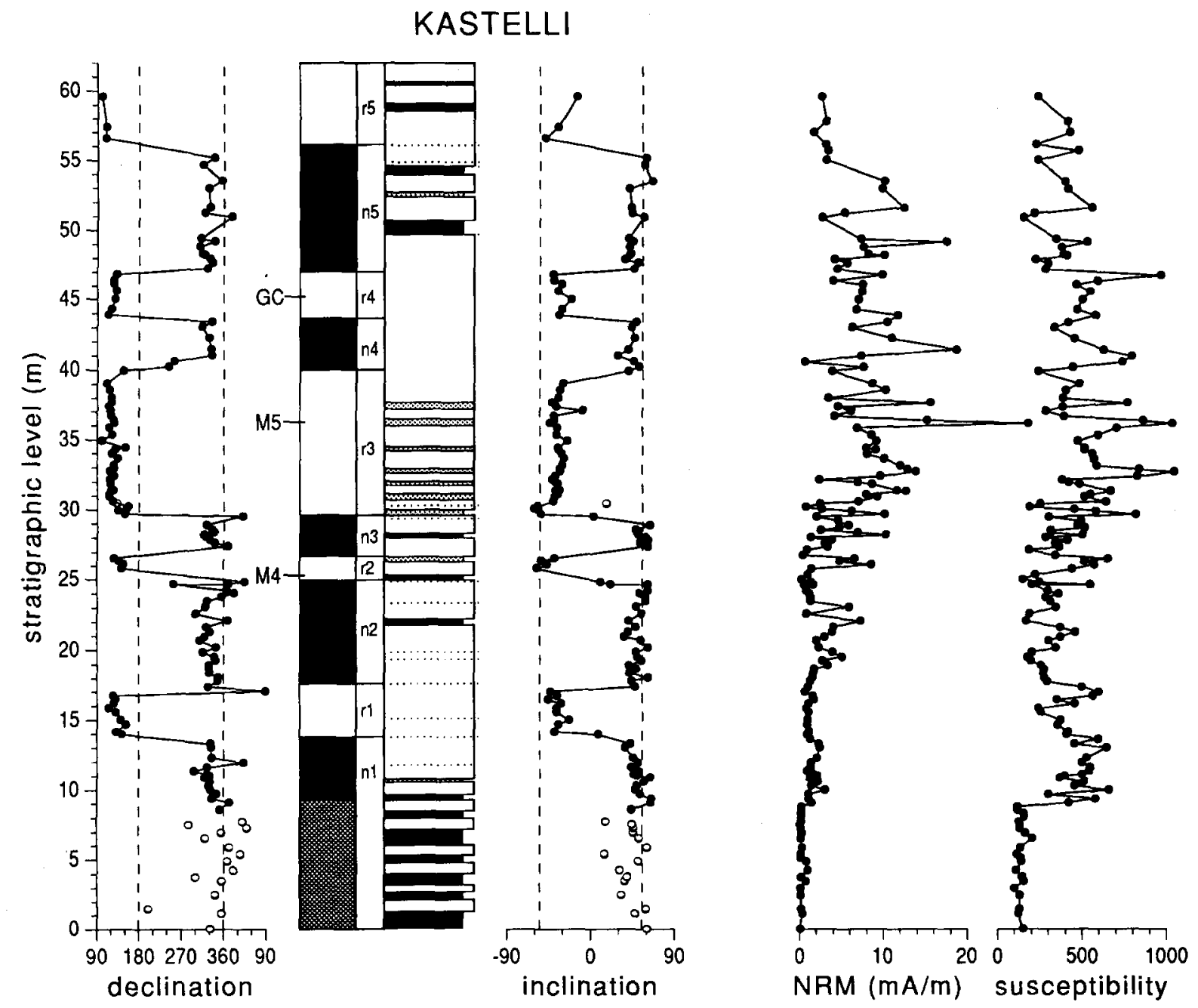

Fig. 3. Magnetostratigraphy, lithology, susceptibility and NRM-intensities of the Kastelli section. See also caption to Fig. 2. Dotted lines in the lithological column are sandy interbeds. 
similar to those of the Faneromeni section. The earlier-sampled section [1] has been resampled and extended downward (Fig. 3).

The sections on western Crete (Fig. 1) near the villages of Potamida and Skouloudhiana have previously been studied and sampled in detail [1]. We have not resampled the Potamida sections but constructed a composite section by combining Potamida 1 and 3 (Fig. 4). The Skouloudhiana section (Fig. 5) consists of a lower and upper part, separated by a non-exposed interval. We extended the upper Skouloudhiana section downward by several metres but did not succeed in closing the stratigraphic gap. Since we cannot exclude the existence of faults in the non-exposed interval, the relation between the two sections remains uncertain. In this paper, we only discuss the results of the upper Skouloudhiana section because it overlaps but also extends the composite Potamida section.

Palaeomagnetic samples were taken with an average spacing of approximately $30 \mathrm{~cm}$. This corresponds to 4-7 sample levels per sedimentary cycle. In the Faneromeni section, 208 levels were sampled, in the Kastelli section 164 levels. At each level, we took standard palaeomagnetic cores (25 mm diameter) with an electric drill and a generator as power supply. As routine procedure, we removed the weathered surface in order to drill in sediments as fresh as possible. For the Potamida 1 and 3 sections and the upper Skouloudhiana section we have used the thermal

\section{POTAMIDA COMPOSITE (1 AND 3)}
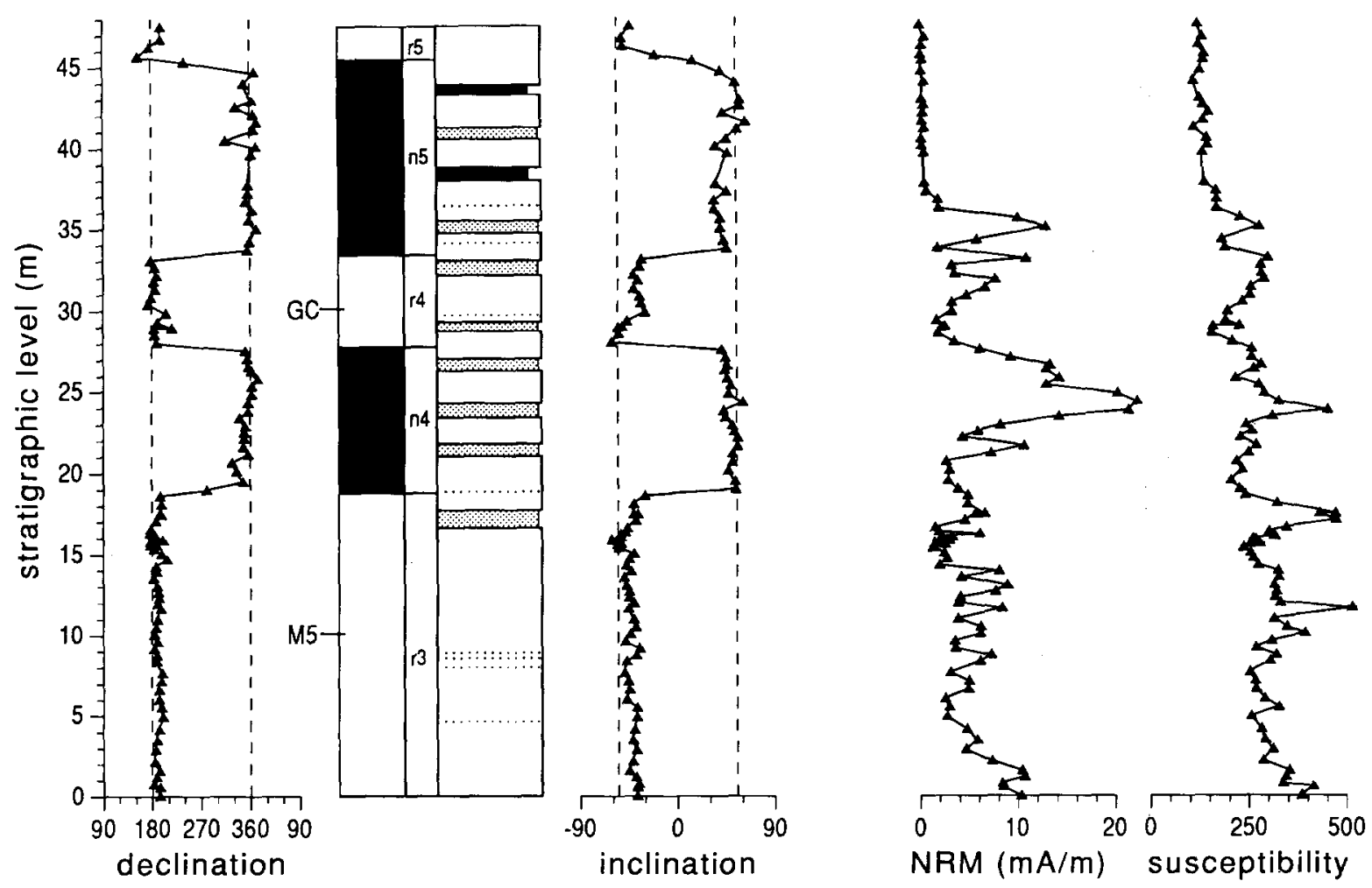

Fig. 4. Magnetostratigraphy, lithology, susceptibility and NRM-intensities of the Potamida section. The data are from the thermally demagnetised specimens of the earlier sampling of Langereis et al. [1]. See captions to Fig. 2 and 3. 
demagnetisation data of Langereis et al. [1]. In the latter section, an additional 52 levels were sampled.

\section{Biostratigraphy and cyclostratigraphy}

The planktonic foraminiferal biostratigraphy used in this paper is the one employed in earlier papers and consists of the following sequence of bioevents (in stratigraphic order): LOD of Globorotalia menardii form 4, FOD of Globorotalia menardii form 5, and FOD of the Globorotalia conomiozea group $[1,15,16]$. These bioevents occur in three successive intervals of reversed polarity (r2, r3 and $r 4$; see Figs. 2-5) and provide a solid biostratigraphic framework for correlating upper Tortonian to lower Messinian sections over the entire length of the Mediterranean.
The position of the FOD of Globorotalia menardii form 5 in the resampled Faneromeni section is slightly below the position reported by Langereis [19]. This modification is caused by the much higher resolution in the present Faneromeni section.

All studied sections show a distinct cyclic bedding (see Fig. 2-5). At Faneromeni, the sedimentary cycles consist of bipartite depositional sequences displaying distinct grey-white colour variations in which the grey beds are less indurated. In the upper half of the section, sapropels start to occur within, or completely substitute, grey beds (of the grey-white colour cycles). At Kastelli, sedimentary cycles mainly consist of sapropel-marl alternations. Sapropel-containing intervals alternate with thick homogeneous marl intervals in which the cyclic bedding is less obvious. Nevertheless, variations in induration of the marls are

\section{UPPER SKOULOUDHIANA}
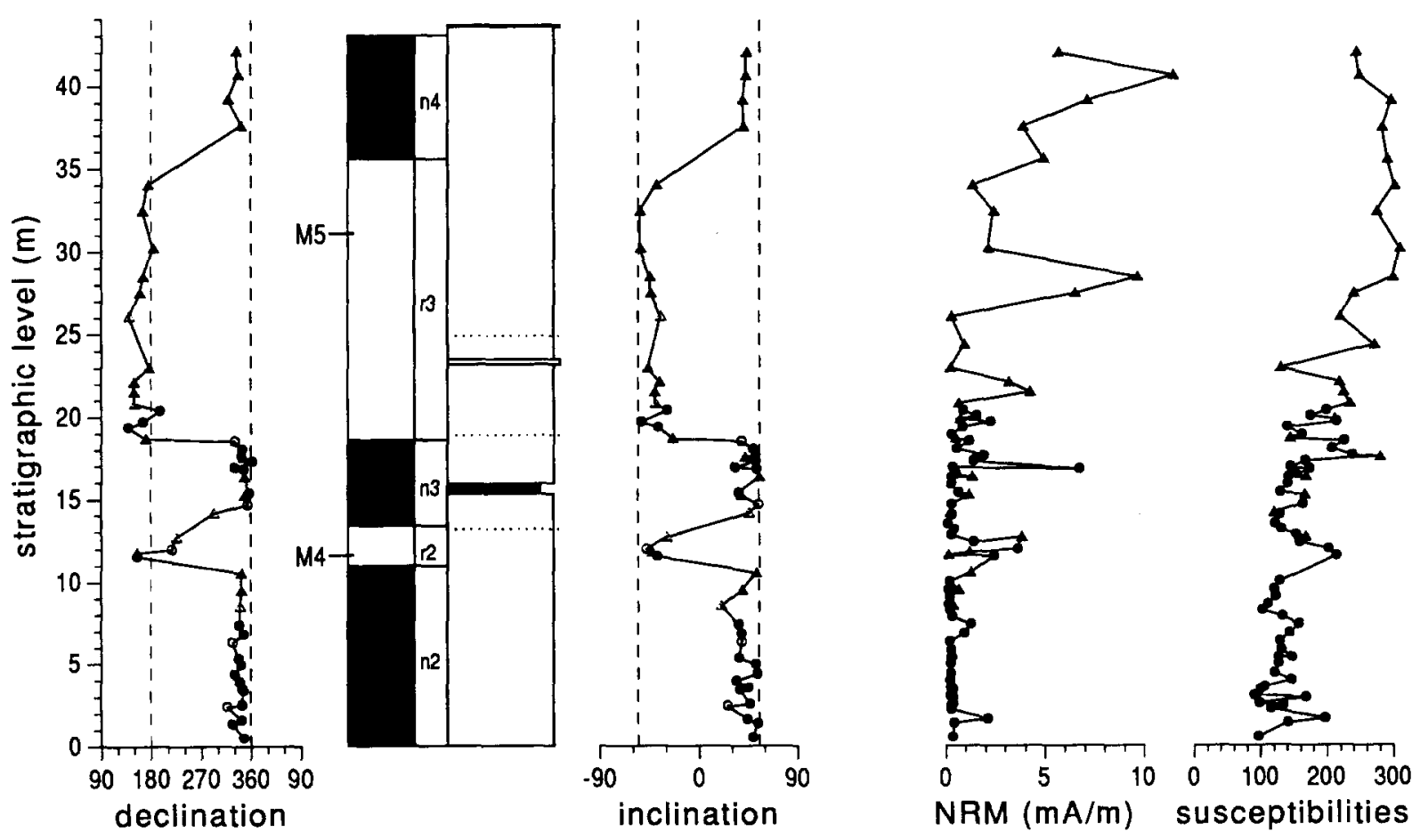

Fig. 5. Magnetostratigraphy, lithology, susceptibility and NRM-intensities of the Skouloudhiana section. Triangles represent data derived from the thermally demagnetised specimens of the earlier sampling of Langereis et al. [1]; dots and circles are from this study. See captions to Fig. 2 and 3. 
present which resemble the bipartite grey-white colour cycles at Faneromeni. Although not as distinct as at Faneromeni and Kastelli, also the
Potamida composite section shows typical variations in colour and, more evident, in induration, especially in the middle and upper part of the

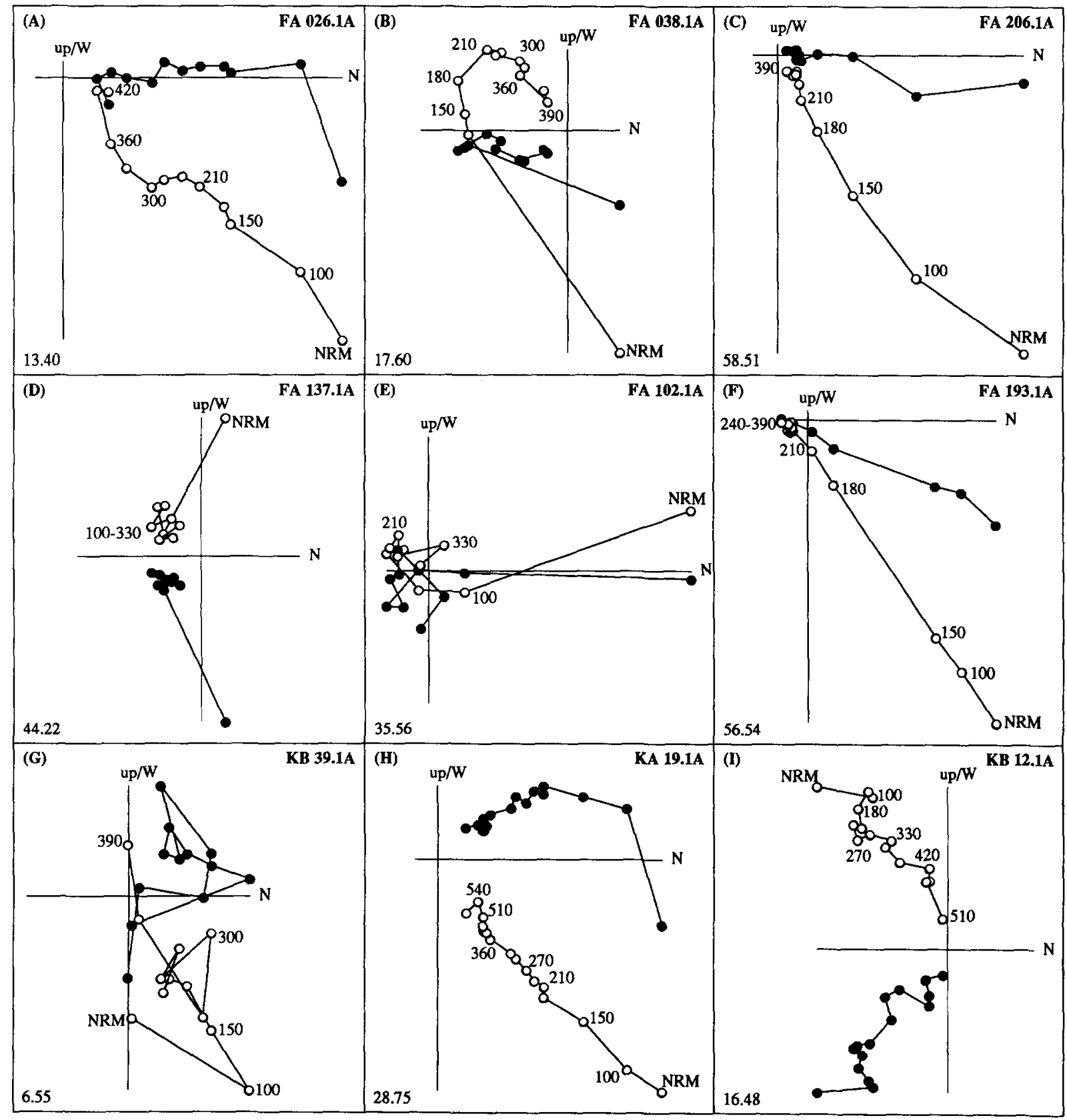

Fig. 6. Orthogonal projections of stepwise thermal demagnetisation of selected samples from the Faneromeni $(F A)$ and Kastelli $(K A)$ sections. Dots represent the projection of the ChRM vector end-point on the horizontal plane and circles the projection of the ChRM vector end-point on the vertical plane. Values represent temperatures in ${ }^{\circ} \mathrm{C}$; stratigraphic levels are in the lower left corners. 
section (Fig. 4). In the uppermost part, two distinct sapropel layers are present. In the lower part of the section, the variations in colour and induration are more difficult to interpret. Here, the vague colour variations have not been indicated in Fig. 4, but may point to quadripartite rather than to bipartite sedimentary cycles.

Together with the magnetostratigraphic and biostratigraphic results, a consistent and coherent cyclostratigraphy starts to emerge for the Mediterranean Upper Miocene with the same potential as the well-established cyclostratigraphies for the Mediterranean Pliocene and Lower Pleistocene [20-22] and the Upper Pleistocene [23]. The two oldest sapropels in the Faneromeni section-which occur in polarity zone n5 (Fig. 2) - can be recognised in all sections except Skouloudhiana where this stratigraphic level is not reached. The three sapropels, which occur in the successive polarity zones $\mathrm{n} 2, \mathrm{r} 2$ and $\mathrm{n} 3$ at Kastelli and which alternate with regular grey-white cycles, provide another sapropel pattern. Although no sapropels are present in the correlative part of the Faneromeni section, three thick grey marlbeds, containing numerous thin sandbeds, can be correlated with these three sapropels (see Fig. 2).

\section{Magnetostratigraphy}

The bulk susceptibility of the samples was measured on a Kappabridge KLY-2. The natural remanent magnetisation (NRM) was measured on a $2 \mathrm{G}$ Enterprises cryogenic magnetometer. At least one specimen from each sampling level was progressively demagnetised by applying stepwise thermal demagnetisation with small $\left(30-50^{\circ} \mathrm{C}\right)$ temperature increments.

\subsection{Eastern Crete: Faneromeni}

In the Faneromeni section, the NRM shows very low intensities in the lower and upper part of the section, and relatively high intensities-one order of magnitude higher-in the middle part (Fig. 2). Thermal demagnetisation (Fig. 6A-6F) shows that in most samples a small viscous and laboratory-induced component is removed at $100^{\circ} \mathrm{C}$. A relatively small secondary present-day field component is removed at $200-225^{\circ} \mathrm{C}$. A characteristic remanent magnetisation (ChRM) is usually totally removed at temperatures ranging from $300^{\circ} \mathrm{C}$ to $400^{\circ} \mathrm{C}$. Further demagnetisation at higher temperatures mainly results in a randomly directed viscous magnetisations. Especially for the samples with relatively high NRM intensities, the ChRM direction can reliably be determined (Fig. $6 \mathrm{~A}$ and $6 \mathrm{~B}$ ). The demagnetisation diagrams of samples with a lower NRM often show a cluster with temperatures ranging from $240^{\circ} \mathrm{C}$ to $390^{\circ} \mathrm{C}$ (Fig. 6C and 6D). Here, a characteristic direction cannot accurately be determined but the normal or reversed polarity is in most cases unambiguous. Several levels show results which are less reliable because of a very weak magnetic signal (Fig. 6E and 6F); the interpreted directions of these samples are plotted with a circle in Fig. 2.

The ChRM directions and polarity zones (Fig. 2) show that eight polarity reversals are recorded in the Faneromeni section. Unfortunately, two intervals of the section show such a low intensity that directions and even polarities are uncertain. Especially in the interval above the normal zone $\mathrm{n} 5$, some samples tend to show-although inconsistently-a reversed polarity (Fig. 6E). Such a reversed polarity, however, is not in good agreement with the unambiguous results of the other time-equivalent Cretan sections. In the uppermost part of the section, the $\mathrm{r} 5 / \mathrm{r} 6$ polarity reversal is accompanied by low intensities; the sedimentary cycles are in this part rather thin.

The susceptibility record of the Faneromeni section (Fig. 2) shows that maximum values of susceptibility coincide with the grey intervals of the sedimentary cycles. Hence, the susceptibility record can be used for estimating the number of cycles in parts of the sections in which the cyclic bedding is less distinct. We assume, for instance, that the maximum in susceptibility within the anomalously thick white interval just below the first sapropeletic layer in Faneromeni represents an extra "grey interval". This indicates that this white interval actually consists of two sedimentary cycles. 


\section{BKFV85 CK92}

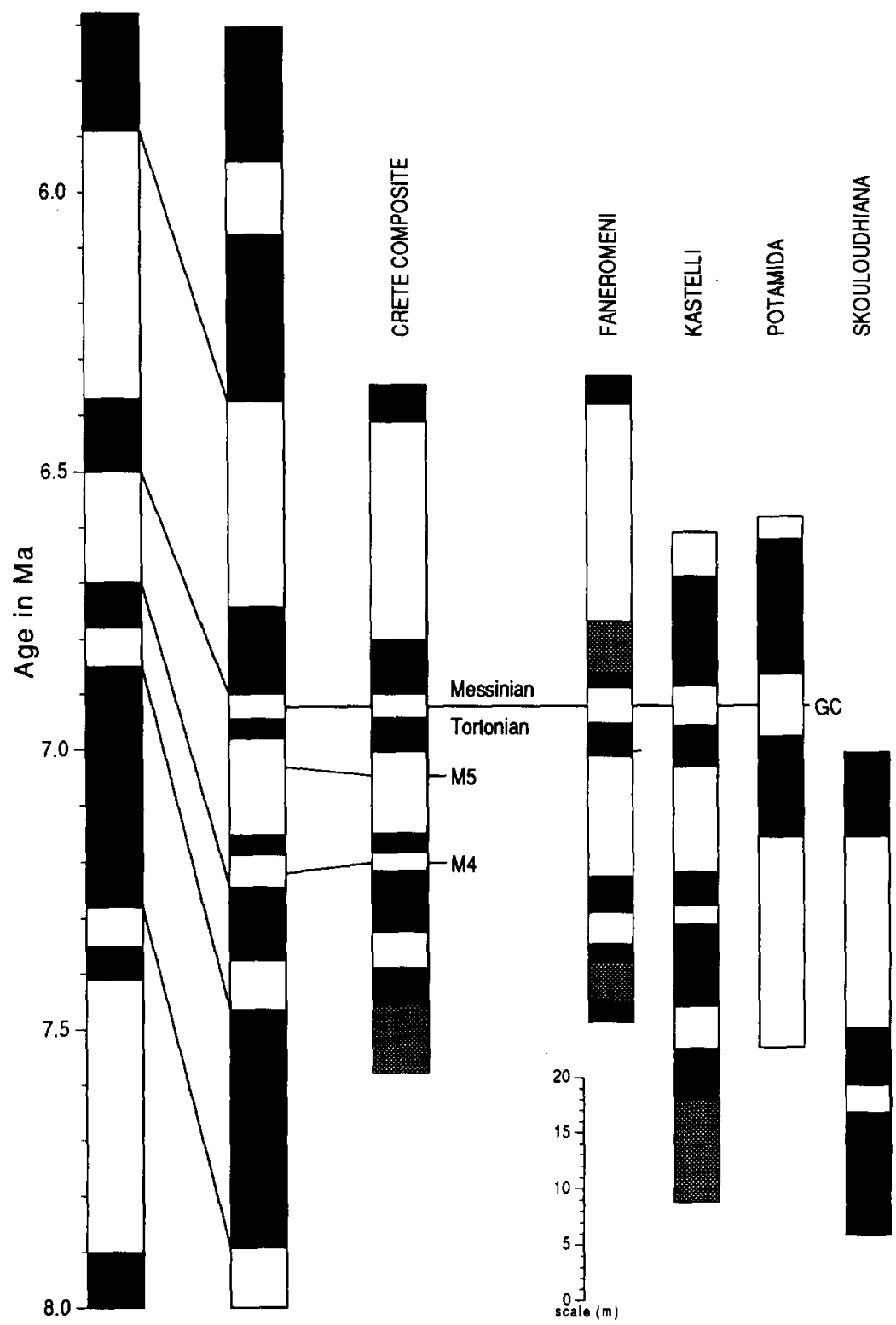

Fig. 7. Correlation of the Cretan polarity sequences with the GPTS of Berggren et al. (BKFV85) [7] and of Cande and Kent (CK92) [2]. Lines connect the same reversal boundaries and emphasize the difference in polarity pattern between the two time scales. The polarity zones of the Crete composite column are given as astronomical durations derived from the number of precession-related sedimentary cycles (Table 1). Polarity zones of the four Cretan sections (Faneromeni, Kastelli, Potamida and Skouloudhiana) are given in stratigraphic distances. Biostratigraphic markers $G C$ (= Tortonian/Messinian boundary), M5 and M4 as in caption to Fig. 2. 


\subsection{Central Crete: Kastelli}

The NRM intensities in the Kastelli section are much higher than in the Faneromeni section and range from 1 to $20 \mathrm{~mA} / \mathrm{m}$. The highest intensities occur, just like in Faneromeni, in the magnetic zone r3 (Fig. 3). Thermal demagnetisation shows the same characteristics as in the previous study of Langereis et al. [1]. After removing a laboratory-induced magnetisation at $100^{\circ} \mathrm{C}$, the demagnetisation diagrams generally reveal a stable and well-defined characteristic remanent magnetisation (Fig. $6 \mathrm{H}$ and $6 \mathrm{I}$ ). Since most of the magnetisation is removed at temperatures of approximately $580^{\circ} \mathrm{C}$, it can be concluded that magnetite is the main carrier of the remanence. In some samples, the remanence is only completely removed at temperatures above $600^{\circ} \mathrm{C}$, which suggests that some hematite or cation-deficient magnetite [24] is also present.

Nine polarity reversals are recorded in the Kastelli section. The biostratigraphic and magnetostratigraphic evidence indicates that the section contains two extra polarity zones that are older than the ones recorded in the Faneromeni section (n1,r1; Fig. 3). The ChRM-direction and polarity are mostly unmistakable (Fig. $6 \mathrm{H}$ and 6I), except for the lowermost part of the section where the results are less reliable (Fig. $6 \mathrm{G}$ ). The large tectonic rotation of the area $\left(42^{\circ}\right)$ [19] helped us to distinguish primary from secondary normal components. The normal zones $\mathrm{n} 2$ and $\mathrm{n} 5$, which showed ambiguous results at Faneromeni, are here unequivocally established.

The susceptibility of the Kastelli section is higher than at Faneromeni (Fig. 3). Maximum values in susceptibility coincide also in Kastelli with the grey parts of the sedimentary cycles. It allows us to estimate the number of sedimentary cycles in the parts of the section where lithological variations are less evident.

\subsection{Western Crete: Potamida and Skouloudhiana}

Both the Potamida and Skouloudhiana sections show in general excellent demagnetisation characteristics [1]. NRM intensities are rather high, especially in Potamida and the upper part of Skouloudhiana, which corresponds to the same magnetic polarity interval as in Faneromeni and Kastelli.

The magnetostratigraphic record of the Potamida section as well as the Skouloudhiana section reveals four polarity reversals. The position of the biostratigraphic datum levels show that the lowermost reversal boundary $(\mathrm{R}-\mathrm{N})$ in Potamida corresponds to the uppermost one in Skouloudhiana (Fig. 4 and 5).

Again, in the Potamida composite section, the greyish-coloured, indurated beds correlate with relative maxima of susceptibility (Fig. 4). Therefore, they may be considered as the equivalent of the grey parts of the sedimentary cycles known from Faneromeni.

\section{Discussion}

The magnetostratigraphic results of the present study essentially confirm the earlier results of Langereis [19]. The upward extension of the Faneromeni section resulted in the registration of an extra polarity reversal (from $\mathrm{R}$ to $\mathrm{N}$ ). The only evidence in all sections for hiatuses is the bedding-parallel shear plane in polarity zone $n 4$ of the Faneromeni section. This shear plane marks only a minor hiatus. The LOD of $G$. menardii form 4, the FOD of $G$. menardii form 5 and the FOD of $G$. conomiozea, are in all sections found in three $(r 2, r 3, r 4)$ successive periods of reversed polarity. Combining the results of the Cretan sections shows that the polarity patterns of all sections are in good agreement and that in total ten polarity reversals and hence nine complete polarity zones have been recorded.

\subsection{Correlation with $\mathrm{CK} 92$}

The first step is to find out whether we can correlate the Cretan polarity sequences to the new time scale (CK92) of Cande and Kent [2] on the basis of the polarity pattern alone. The correlations of Langereis et al. [1] and Berggren et al. [7] of the Cretan polarity sequence to the commonly used GPTS [6,7] have led to considerable controversy. However, the CK92 time scale shows 
more detail in the Late Miocene with respect to the time scale of Berggren et al. (BKFV85). In particular, the former Chron 6 of BKFV85 contains two additional short normal subchrons in CK92. This substantially modifies the polarity pattern during this time interval and allows an unambiguous correlation of the Cretan polarity sequences to CK92 (Fig. 7). Furthermore, it can now be concluded that neither the correlation of Langereis et al. [1] nor the one of Berggren et al. [7] was correct. Finally, Channell et al. [8] appear to have missed the short reversed interval of anomaly C3Bn.1r in ODP Site 654, since they found the FOD of $G$. conomiozea in an interval of normal polarity.

The different and more detailed polarity pattern of CK92 for the Late Miocene solves the previous correlation problems. The new correlation results in an age of $6.92 \mathrm{Ma}$ for the FOD of G. conomiozea, and in ages of $7.03 \mathrm{Ma}$ and 7.22 $\mathrm{Ma}$ for the FOD of $G$. menardii form 5 and the LOD of $G$. menardii form 4, respectively. Consequently, the age of the Tortonian/Messinian boundary arrives at $6.92 \mathrm{Ma}$ according to the CK92 time scale. Since the age of the Miocene/ Pliocene boundary is determined at an age of
$5.16 \mathrm{Ma}$ with respect to CK92, the duration of the Messinian is $1.76 \mathrm{Myr}$.

\subsection{Comparison with astronomically derived dura- tions}

Additional support for our present correlation is provided by the sedimentary cycles, assuming that this cyclicity is controlled by the astronomical cycle of precession. This assumption is based on the fact that the observed sedimentary cycles are similar to the sedimentary cycles found in the Mediterranean Plio-Pleistocene: these younger cycles proved to be invariably related to the precession cycle $[20,21]$. Combining the number of cycles in the Faneromeni section with the polarity reversal ages of CK92 enables us to calculate the average duration of the sedimentary cycles. The resulting $23.5 \mathrm{kyr}$ strongly suggest that these cycles are indeed related to the precession cycle which has an average periodicity of $21.7 \mathrm{kyr}$ [25]. Any other correlation to CK92 leads to unrealistic (changes in) sedimentation rates and durations for the cycles. In those parts of the sections where the cyclic bedding is clearly developed, counting of the cycles in individual polarity zones

Table 1

Number of sedimentary cycles in the Faneromeni, Kastelli and west Cretan (Potamida and Skouloudhiana) sections. Bold values represent the number of cycles counted directly from the lithological columns (Figs. 2-5). Italic values represent the number of cycles estimated using the susceptibility record and/or a constant sedimentation rate. Zonation as in Figs. 2-5. Astronomical durations for the individual polarity zones (right column) are estimated using an average periodicity of 21.7 kyr for precession [25].

\begin{tabular}{|c||c|c|c|c|}
\hline zone & \multicolumn{3}{|c|}{$\begin{array}{c}\text { nr. of cycles } \\
\text { Kastelli }\end{array}$} & $\begin{array}{c}\text { West Crete } \\
\text { furation (kyr) } \\
\text { composite }\end{array}$ \\
\hline \hline & $>3$ & & & $>65$ \\
$\mathrm{n} 6$ & 18 & & & 391 \\
$\mathrm{r} 5$ & 4.5 & $4.5-5$ & 4.5 & 98 \\
$\mathrm{n} 5$ & 2 & $2-2.5$ & 2 & 43 \\
$\mathrm{n} 4$ & 2.75 & 2.5 & 2.75 & 60 \\
$\mathrm{n} 4$ & 6.75 & 6.25 & 6.8 & 146 \\
$\mathrm{r} 3$ & 1.5 & 1.5 & 1.5 & 33 \\
$\mathrm{n} 3$ & 1.5 & 1.5 & 1.5 & 33 \\
$\mathrm{n} 2$ & $>3$ & 5 & & 109 \\
$\mathrm{n} 2$ & & 3 & & 65 \\
$\mathrm{rl}$ & & $>9$ & & $>195$ \\
$\mathrm{n}$ & & & & \\
\hline
\end{tabular}


is straightforward. Where sampling took place in sufficient detail, the susceptibility record can also be used. Where necessary, we derived an average thickness of the sedimentary cycles and estimated the number of cycles for those parts which showed no clear cyclic lithology. It appears that the number of cycles per individual polarity zone agrees very well (Table 1 ).

The next step is to use the "true" average periodicity of $21.7 \mathrm{kyr}$ [25] instead of the average periodicity of $23.5 \mathrm{kyr}$ derived from CK92. This enables us to independently estimate the duration of the individual polarity zones in every section (Table 1). We have also used these durations to construct a composite Cretan "astronomical" polarity time sequence (Fig. 7). A comparison of this polarity time sequence with the seafloor-spreading-derived durations of CK92 shows that there is in general a good agreement in the pattern, but the astronomically derived duration ( $978 \mathrm{kyr}$ ) for the complete polarity sequence is $110 \mathrm{kyr}$ shorter than the correlative part in CK92 (1088 kyr; Table 2). This shorter astronomical duration is unexpected because for the Plio-Pleistocene astronomical ages $[20,21,26]$ proved to be invariably older (by 5-7\%) than the ages in the conventional time scales. The variable period of precession-ranging from 14 to $28 \mathrm{kyr}$ for individual cycles [25] — can be held responsible for discrepancies in the duration of individual polarity zones that are relatively short. But it does certainly not explain the $110 \mathrm{kyr}$ discrepancy for the duration of the complete polarity sequence.

An explanation for this discrepancy in duration are errors in the ages of the calibration points of CK92 and/or differences in seafloor spreading rate between the calibration points. Cande and Kent [2] used an astronomical age of $2.60 \mathrm{Ma}$ for the Gauss/Matuyama boundary (C2An (y)) and a radiometric age of $14.8 \mathrm{Ma}$ for the younger end of chron C5Bn.1n (y) [27] to construct the Late Miocene part of CK92. Astronomically derived ages for polarity reversals in

Table 2

Comparison of the astronomically derived duration (right) of the individual polarity zones with the seafloor-spreading-derived duration of the corresponding (sub)chrons in CK92 (left). Note the large difference between the astronomical duration and CK92 for the total Cretan polarity sequence.

\begin{tabular}{|c|c|c|c|c|}
\hline Chron & polarity & duration (kyr) & zone & $\begin{array}{c}\text { duration (kyr) } \\
\text { This study }\end{array}$ \\
\hline \multirow{4}{*}{ C3An. In } & & & & \\
\hline & $R$ & $\infty$ & & \\
\hline & $\mathrm{N}$ & 240 & & \\
\hline & $\mathbf{R}$ & 130 & & \\
\hline \multirow[t]{2}{*}{ C3An.2n } & $\mathrm{N}$ & 300 & no & $>65$ \\
\hline & $\mathbf{R}$ & 368 & r5 & 391 \\
\hline \multirow[t]{2}{*}{$\mathrm{C} 3 \mathrm{Bn}$} & $N$ & 157 & n5 & 98 \\
\hline & $\mathrm{R}$ & 45 & $\mathrm{r} 4$ & 43 \\
\hline \multirow[t]{2}{*}{ C3Br. In } & $N$ & 35 & n4 & 60 \\
\hline & $\mathrm{R}$ & 172 & r3 & 146 \\
\hline \multirow[t]{2}{*}{ C $3 B r .2 n$} & $N$ & 34 & n3 & 33 \\
\hline & $\mathrm{R}$ & 58 & 12 & 33 \\
\hline \multirow[t]{2}{*}{ C4n. In } & $N$ & 131 & $\mathrm{n} 2$ & 109 \\
\hline & $R$ & 88 & $\mathrm{rl}$ & 65 \\
\hline \multirow[t]{2}{*}{$C 4 n .2 n$} & $N$ & 428 & $\mathrm{nl}$ & $>195$ \\
\hline & $\mathrm{R}$ & 155 & & \\
\hline $\begin{array}{l}\text { Total dur } \\
\text { polarity s }\end{array}$ & $\begin{array}{l}\text { The Cretan } \\
\text { e: }\end{array}$ & 1088 & & 978 \\
\hline
\end{tabular}




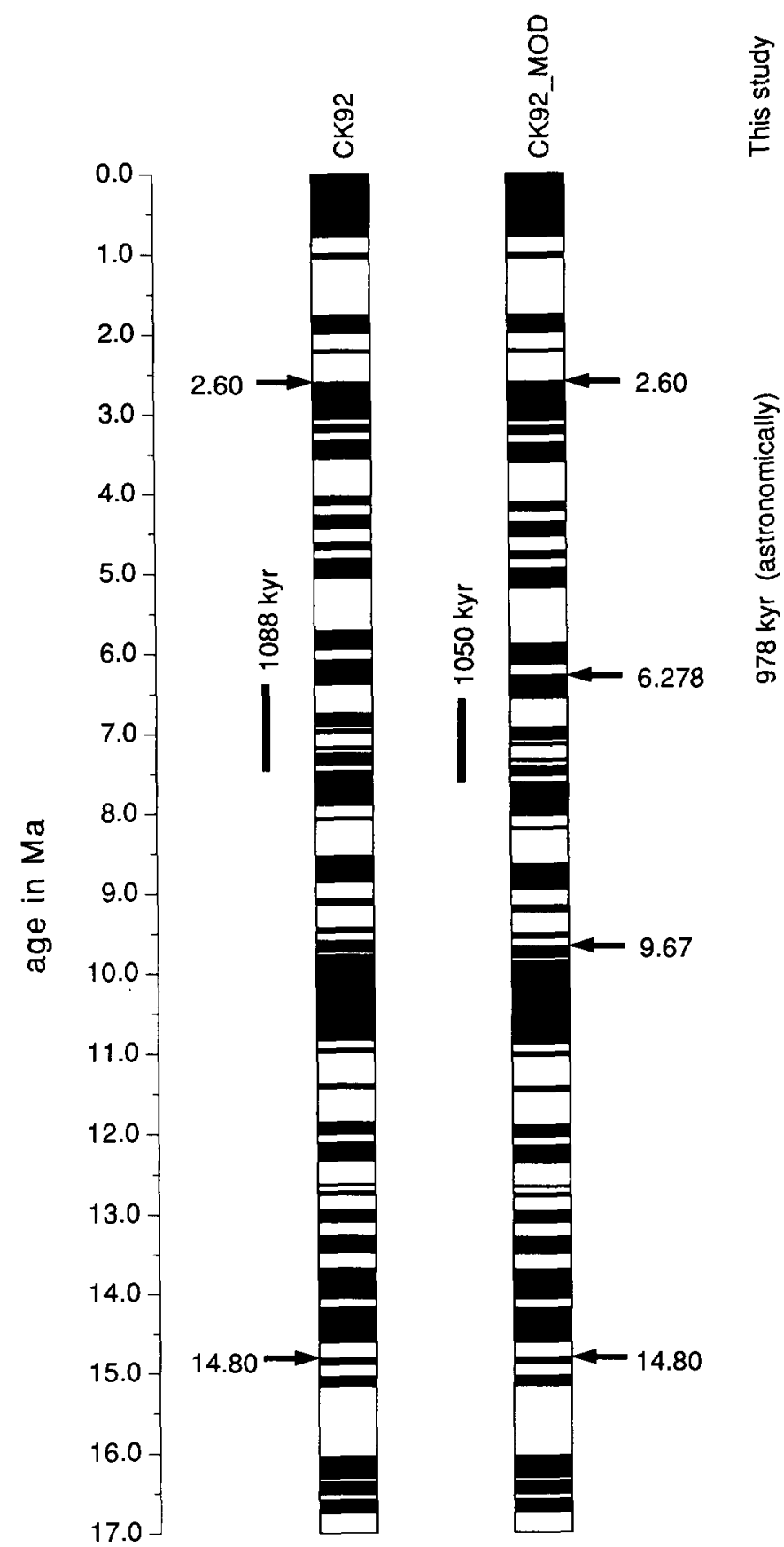

Fig. 8. CK92 time scale (left column) and modified GPTS (CK92-MOD; right column) using new astronomical and radiometric calibration points. For further explanation and references see text. Small black columns indicate the total duration of the composite Cretan polarity sequence correlated straightforwardly to the GPTS. Astronomical duration is derived from the number of precession-induced sedimentary cycles (Table 2). 
the Gilbert Chron and Chron 5, however, are approximately $180 \mathrm{kyr}$ older than in CK92 [21,28]. Furthermore, Baksi [29] obtained an ${ }^{40} \mathrm{Ar} /{ }^{39} \mathrm{Ar}$ age of $9.67 \mathrm{Ma}$ for the younger end of chron C5n (y). This is only $80 \mathrm{kyr}$ older than the interpolated age of $9.592 \mathrm{Ma}$ for the same reversal in CK92.

Incorporating an astronomical age of 6.278 for the younger reversal boundary of chron C3An.2n (y) [28] and a radiometric age of 9.67 for C5n (o) [29] as age calibration points in the CK92 time scale enables us to re-estimate the ages of the polarity reversals. If we use linear interpolation between the two new calibration points, the correlation of the Cretan polarity sequence to the modified polarity pattern (CK92 - MOD; Fig. 8) results in an age of $7.10 \mathrm{Ma}$ for the FOD of $G$. conomiozea and hence also the Tortonian/ Messinian boundary. This age agrees reasonably well with radiometric datings from the northern Apennines, where Vai et al. [30] obtained an age of $7.33 \pm 0.08 \mathrm{Ma}$ biotite-rich layers a few metres below the FOD of $G$. conomiozea. They suggest an age of $7.26 \pm 0.10 \mathrm{Ma}$ for the Tortonian/ Messinian boundary, based on the inferred sedimentation rate. Since the astronomical age of the Miocene/Pliocene boundary is accurately dated at 5.32 Ma [21], the use of CK92 - MOD provides a duration of the Messinian of 1.78 Myr. This duration does not deviate significantly from the $1.76 \mathrm{Myr}$ duration according to CK92.

The modified CK92 time scale results in a reduction, but not in a complete elimination of the $110 \mathrm{kyr}$ discrepancy between the astronomically derived duration of the Cretan polarity sequence and CK92 (Fig. 8). This problem can only be solved after the sedimentary cycles in the Cretan sections have been calibrated directly to the astronomical record.

\section{Conclusions}

We have established detailed magnetostratigraphic, biostratigraphic and cyclostratigraphic records for four upper Tortonian to lower Messinian sections on Crete. Combining these sections enables us to construct a composite polarity sequence which contains ten polarity rever- sals. The recognition of two additional short subchrons in the CK92 time scale, not recorded before in the commonly used time scales, solves the previous correlation problem of the Late Miocene Cretan polarity sequence to the GPTS $[1,7]$. Our correlation implies that the FOD of $G$. conomiozea and hence the Tortonian/Messinian boundary occurs in the short reversed polarity subchron C3Bn.1r of CK92 (or CK92-MOD), resulting in an age of 6.92 (or 7.10) Ma for the $\mathrm{T} / \mathrm{M}$ boundary and a duration of 1.76 (or 1.78) Myr for the Messinian. Furthermore, new ages are derived for the FOD of $G$. menardii form 5 (7.03, or $7.20 \mathrm{Ma})$ and the LOD of G. menardii form $4(7.22$, or $7.38 \mathrm{Ma})$ which are found in successive periods of reversed polarity $(\mathrm{C} 3 \mathrm{Br} .1 \mathrm{r}$, C3Br.2r, respectively).

We used precession-controlled sedimentary cycles to independently estimate the duration of the Late Miocene polarity sequence on Crete. It appears that the astronomically derived duration is $10 \%$ shorter than the duration of the same polarity sequence in CK92. If the most recent astronomical and ${ }^{40} \mathrm{Ar} /{ }^{39} \mathrm{Ar}$ radiometric age determinations are incorporated in the CK92 time scale as new calibration points, this discrepancy is reduced but not completely eliminated.

\section{Acknowledgements}

P.J. Verplak assisted in the field and also measured many of the samples. G.J. van 't Veld and G. Ittman prepared the micropalaeontological samples. G. Postma, I.M. Villa, G.B. Vai and D.V. Kent read an earlier version of the manuscript and provided useful comments. The reviews by C. Laj and Y. Gallet are gratefully acknowledged. This study was partly funded by The Netherlands Organization of Scientific Research (NWO). This is MIOMAR contribution no. 2 .

\section{References}

[1] C.G. Langereis, W.J. Zachariasse and J.D.A. Zijderveld, Late Miocene magnetobiostratigraphy of Crete, Mar. Micropalaeontol. 8, 261-281, 1984. 
[2] S.C. Cande and D.V. Kent, A New Geomagnetic Polarity Time Scale for the Late Cretaceous and Cenozoic, J. Geophys. Res. 97, 13917-13951, 1992.

[3] S. d'Onofrio, L. Gianelli, S. Iaccarino, E. Morlotti, E. Romeo, G. Salvatorini, M. Sampo and R. Sprovieri, Planktonic foraminifera of the Upper Miocene from some Italian sections and the problem of the lower boundary of the Messinian, Boll. Soc. Paleontol. Ital. 14, 177-196, 1975.

[4] M.L. Colalongo, A. di Grande, S. d'Onofrio, L. Gianelli, S. Iaccarino, R. Mazzei, M.F. Poppi Brigatti, M. Romeo, A. Rossi and G. Salvatorini, A proposal for the Tortonian-Messinian boundary, Ann. Geol. Pays Hell., Tome hors ser., fasc. I, 285-294, 1979.

[5] C.G. Langereis and M.J. Dekkers, Paleomagnetism and rock magnetism of the Tortonian-Messinian boundary stratotype at Falconara, Sicily, Phys. Earth Planet. Inter. $71,100-111,1992$.

[6] W. Lowrie and W. Alvarez, One hundred million years of geomagnetic polarity history, Geology 9, 392-397, 1981.

[7] W.A. Berggren, D.V. Kent, J.J. Flynn and J.A. Van Couvering, Cenozoic geochronology, Geol. Soc. Am. Bull. 96, 1407-1418, 1985.

[8] J.E.T. Channell, M. Torii and T. Hawthorne, Magnetostratigraphy of sediments recovered at Sites 650,651 , 652, and 654 (Leg 107, Thyrrhenian Sea), Proc. ODP, Sci. Results 107, 335-346, 1990.

[9] K. Kastens, Did a glacio-eaustatic sealevel drop trigger the Messinian salinity crisis? New evidence from ODP Site 654 in the Tyrrhenian Sea, EOS 70, 1135, 1989.

[10] T.S. Loutit and J.P. Kennett, Application of carbon isotope stratigraphy to Late Miocene shallow marine sediments, New Zealand, Science 204, 1196-1199, 1979.

[11] M.G. Moreau, H. Feinberg and J.P. Pozzi, Magnetobiostratigraphy of a Late Miocene section from the Moroccan Atlantic margin, Earth Planet. Sci. Lett. 76, 167-175, 1985.

[12] D.A. Hodell and J.P. Kennett, Late Miocene-Early Pliocene stratigraphy and paleoceanography of the South Atlantic and Southwest Pacific: a synthesis, Paleoceanography $1,285-311,1986$.

[13] A.R. Edwards, Significant climatic vents in the Late Neogene marine strata of New Zealand, in: 4th Int. Congr. Pacific Neogene Stratigraphy, J.A. Barron and J.R. Blueford, eds., pp. 26-27, 1987.

[14] G.M. Turner, A.P. Roberts, C. Laj, C. Kissel, A. Mazaud, S. Guitton and D.A. Christoffel, New paleomagnetic results from Blind River: revised magnetostratigraphy and tectonic rotation of the Marlborough region, South Island, New Zealand, N.Z.J. Geol. Geophys. 32, 191-1961, 1989.

[15] W.J. Zachariasse, Planktonic foraminiferal biostratigraphy of the Late Neogene of Crete (Greece), Utrecht Micropalaeontol. Bull. 11, 1975.

[16] W.J. Zachariasse, The origin of Globorotalia conomiozea in the Mediterranean and the value of its entry level in biostratigraphic correlations, Ann. Geol. Pays Hell., Tome hors ser., fasc. III, 7th Int. Congr. Mediterranean Neogene, Athens, pp. 1281-1292, 1979.

[17] G.H. Scott, Upper Miocene biostratigraphy: does Globorotalia conomiozea occur in the Messinian? Rev. Esp. Micropaleontol. 12, 489-506, 1980.

[18] F.J. Hilgen and C.G. Langereis, A critical re-evaluation of the Miocene/Pliocene boundary as defined in the Mediterranean, Earth Planet. Sci. Lett. 118, 167-179, 1993.

[19] C.G. Langereis, Late Miocene magnetostratigraphy in the Mediterranean, 180 pp, Ph.D. Thesis, Univ. Utrecht, Geol. Ultraiectina 34, 1984.

[20] F.J. Hilgen, Astronomical calibration of Gauss to Matayama sapropels in the Mediterranean and implication for the Geomagnetic Polarity Time Scale, Earth Planet. Sci. Lett. 104, 226-244, 1991.

[21] F.J. Hilgen, Extension of the astronomically calibrated (polarity) time scale to the Miocene/Pliocene boundary, Earth Planet. Sci. Lett. 107, 349-368, 1991.

[22] C.G. Langereis and F.J. Hilgen, The Rossello composite: a Mediterranean and global reference section for the Early to early Late Pliocene, Earth Planet. Sci. Lett. 104, 211-225, 1991

[23] W.B.F. Ryan, Stratigraphy of Late Quarternary sediments in the eastern Mediterranean, in: The Mediterranean Sea: A Natural Sedimentation Laboratorium, D.J. Stanley, ed., pp. 146-169, Dowden, Hutchinson and Ross, Stroudsburg, Pa., 1972.

[24] F. Heider and D.J. Dunlop, Two types of chemical remanent magnetization during oxidation of magnetite, Phys. Earth Planet. Inter. 46, 24-45, 1986.

[25] A. Berger, Accuracy and frequency stability of the Earth's orbital elements during the Quarternary, in: Milankovitch and Climate, A.L. Berger, J. Imbrie, J. Hays, G. Kukla and B. Salzman, eds., pp. 3-39, NATO ASI Ser. C, 126, Reidel, Dordrecht, 1984.

[26] N.J. Shackleton, A. Berger and W.R. Peltier, An alternative astronomical calibration of the lower Pleistocene time scale based on ODP Site 667, Trans. R. Soc. Edinburgh Earth Sci. 81, 251-261, 1990.

[27] K.G. Miller, M.J. Kahn, M.P. Aubry, W.A. Berggren, D.V. Kent and A. Melillo, Oligocene to Miocene bio-, magneto-, and isotope stratigraphy of the western North Atlantic, Geology 13, 257-261, 1985.

[28] N.J. Shackleton, S. Crowhurst, T. Hagelberg, N. Pisias and D.A. Schneider, $A$ new late Neogene timescale: application to ODP leg 138 sites, Proc. ODP, Sci. Re sults, 138, in press, 1993.

[29] A.K. Baksi, A geomagnetic polarity time scale for the period 0-17 $\mathrm{Ma}$, based on ${ }^{40} \mathrm{Ar} /{ }^{39} \mathrm{Ar}$ plateau ages for selected field reversals, Geophys. Res. Lett. 20(15), 1607-1610, 1993.

[30] G.B. Vai, I.M. Villa and M.L. Colalongo, First direct radiometric dating of the Tortonian/Messinian boundary, C.R. Acad. Sci. Paris 316, Ser. II, 1407-1414, 1993. 